\title{
Effect of Herbal Immunomodulator on Dressing Percentage and Carcass Characteristics of Giriraja Birds
}

\author{
G.Y. Dharmaraj, Jayanaik, H.C. Indresh ${ }^{*}$ and T. Munegowda
}

\author{
Department of Poultry Science, Veterinary College, Hebbal, Bangalore, Karnataka, India \\ *Corresponding author
}

Keywords

Dressing percentage, Immunomodulator, Liver, Gizzard, Abdominal fat.

Article Info

Accepted:

19 July 2017

Available Online:

10 September 2017
A B S T R A C T

An experiment was conducted to evaluate the effects of Herbal immunomodulator powder and liquid form (with and without vaccine) comparing with Levamisole powder (with and without vaccine) on dressing percentage in Giriraja birds. In a completely randomised design, 525 day old Giriraja chicks were assigned to seven treatments with each treatment group consisting of five replicates with 15 chicks each. The results of the present study found that the dietary supplementation group had no significant effect on dressing percentage of birds. The abdominal fat percentage was non-significant difference in treatment groups, but higher level of abdominal fat per cent was recorded in herbal immunomodulator liquid without vaccine supplemented group $\left(\mathrm{T}_{6}\right)$. There is no significant effect on the relative weight of the liver and gizzard when compared to control group and also among the various treatment groups. Herbal immunomodulator powder with vaccine supplemented group had higher heart per cent compared to control and levamisole with vaccine and herbal immunomodulator with vaccine supplemented groups. There is no significant difference in the relative weight of the breast and thigh muscle. There is significant difference in relative weight of the immune organ thymus in levamisole powder (with vaccine) $\mathrm{T}_{3}$ and herbal immunomodulator in powder without vaccine $\left(\mathrm{T}_{4}\right)$ and nonsignificant in other treatment groups when compared other treatment groups and control groups.

\section{Introduction}

In India, poultry industry is recognized as an important cottage as well as fast growing large commercial agriculture industry. Sustained economically viable poultry production demands the stringent control of various infectious diseases affecting the birds which result in huge economic losses to the poultry farm owners (Ganguly and Prasad, 2010). Broiler production in India has continuously faced challenges of providing optimum environment for maximum growth, production, disease control and finally the cost benefit ratio involved for a successful poultry husbandry practices. Antibiotics as antimicrobial growth promoters have been widely used in the poultry feed industry. The advantages of using antibiotics as feed additives in terms of growth stimulation and improvement of feed efficiency are well documented (Ensminger et al., 1990).

The ban on the use of antibiotics as feed additives has accelerated and led to investigations of alternative feed additives in 
animal production. As one of the alternatives, herbal extracts are already being used as feed additives to improve the growth performance under intensive management systems (William and Losa, 2001).

Many medicinal plants showing immunomodulatory activity have been used instead of drugs because of their low toxicity for the host system, adequate absorption and capability to reach the target organ without much degradation by host enzymes (Arivuchelvan et al., 2012). Keeping the above points in view, there is a great need to utilize the alternative unconventional feed additives such as herbal products to reduce the gap between cost of production and benefits in successful poultry production. Hence, the current study was designed to investigate the possible effect of these products independently or in combination with the following objective.

\section{Materials and Methods}

Five hundred and twenty five day old straight run Giriraja chicks from a single hatch were wing banded for identification, weighed and randomly distributed to seven treatment groups in Completely Randomised Design. Each treatment had five replicates with 15 birds in each replicate. All the experimental chicks were healthy and received normal routine health care during eight weeks of the trial. The birds were provided feed and water ad libitum. A practical diet comprising of Yellow Maize, Soya bean meal, feed supplements and feed additives without antibiotics and coccidiostat constituted the control diet for all the seven treatment groups. The feed for the treatment group was formulated as per BIS (1994) requirements for all the nutrients except antibiotics and coccidiostat. The experimental birds in $\mathrm{T}_{1}$ were fed with control diet without any antibiotics and coccidiostat. The birds were administered with ND and IBD vaccines. The experimental birds in $\mathrm{T}_{2}$ were fed as in $\mathrm{T}_{1}$ and supplemented with Levamisole powder. The experimental birds in $T_{3}$ were fed as in $T_{2}$ and administered vaccines. The experimental birds from $\mathrm{T}_{4}$ and $\mathrm{T}_{5}$ were fed with Herbal Immunomodulator preparation in powder form containing Mandukaparni, Yasthi madhu, Guduchi, vriddadaru, Amalaki, Nimba and etc., without and with vaccines, respectively and birds from $T_{6}$ and $T_{7}$ were fed with Herbal Immunomodulator preparation in liquid form containing Himsara, Kasani, Vasaka, Guduchi, Daraksha, Jhavuka, Shatavari etc., without and with administration of vaccines, respectively against ND and IBD (Table 1).

\section{Results and Discussion}

The results of dressing percentage and carcass characteristics as affected by supplementing herbal immunomodulator in both powder and liquid form (with and without vaccine) and levamisole powder (with and without vaccine) on dressing percentage and abdominal fat percentage (Table 2).

Among the various treatment groups, levamisole powder with vaccine supplemented $\left(\mathrm{T}_{3}\right)$ group showed highest dressing percentage of 78.82 as against the lowest of 74.14 per cent in group supplemented with herbal immunomodulator liquid with vaccine $\left(\mathrm{T}_{7}\right)$.

However, herbal immunomodulator powder (with and without vaccine recorded significantly higher dressing percentage compared to liquid (with and without vaccine). The herbal immunomodulator powder (with and without vaccine) supplemented groups $\left(\mathrm{T}_{4}\right.$ and $\left.\mathrm{T}_{5}\right)$ were nonsignificantly comparable with group supplemented with levamisole with and without vaccine $\left(\mathrm{T}_{2}\right.$ and $\left.\mathrm{T}_{3}\right)$. 
The results of the present study showed that there was no significant effect of supplementation of herbal immunomodulator powder and liquid (with and without vaccine) on dressing percentage when compared to the group supplemented with levamisole with vaccine group $\left(T_{3}\right)$. The results of the present study are also in agreement with the finding of Basmacioblus et al., (2004) who found no beneficial effect of dietary supplementation of oregano essential oil and thyme powder respectively, on the carcass yield of broiler chickens. The results shown that there was no significant difference in dressing percentage in treatment groups when compared to control.

Herbal immunomodulator liquid without vaccine supplemented group $\left(\mathrm{T}_{6}\right)$ showed highest abdominal fat percentage of 2.53 as against the lowest of 1.67 per cent recorded in control group $\left(\mathrm{T}_{1}\right)$. Salarya et al., (2014) Observed that by feeding diet with the inclusion of 0.2 and $0.4 \%$ of Aloe vera and the inclusion of 0.2 and $0.4 \%$ licorice on abdominal fat and organelles weight in all treatments led to significantly reduction in abdominal fat weights at 21 and 42 days of age $(\mathrm{P}<0.05)$.
The results effect of herbal immunomodulator powder and liquid form and levamisole powder are showed a non-significant difference in relative weights of liver and gizzard and significant difference of heart among various treatment groups.

Among various treatment groups, levamisole without vaccine supplemented group $\left(\mathrm{T}_{2}\right)$ showed maximum liver weight of 2.35 per cent as against the lowest relative liver weight of 2.23 per cent recorded in herbal immunomodulator liquid without vaccine supplemented group $\left(\mathrm{T}_{6}\right)$. There was no significant difference $(\mathrm{P}>0.05)$ in relative liver weights among various treatment groups when compared to control and also among the treatment groups supplemented with herbal immunomodulator (powder and liquid) and levamisole supplemented groups.

The present results are also in agreement with the findings of Raghdad and Al-Jaleel, (2012) revealed that the effect of turmeric in broiler diet on the giblets traits' (i.e., Dressing, Liver, Gizzard, Heart\%) at 6 weeks of age, results showed no significant $(\mathrm{P}<0.05)$ differences in giblets of treated group as compared with control group.

Table.1 Description of experimental treatment diets

\begin{tabular}{|c|l|c|c|}
\hline Treatment & $\begin{array}{l}\text { Feed } \\
\text { type }\end{array}$ & $\begin{array}{l}\text { Levamisole/Herbal immunomodulator } \\
\text { powder/Herbal immunomodulator liquid }\end{array}$ & $\begin{array}{l}\text { Vaccine administered } \\
(+) \text { or Not(-) }\end{array}$ \\
\hline $\mathrm{T}_{1}$ & Control & - & + \\
\hline $\mathrm{T}_{2}$ & Control & Levamisole & + \\
\hline $\mathrm{T}_{3}$ & Control & Levamisole & + \\
\hline $\mathrm{T}_{4}$ & Control & Herbal immunomodulator powder & + \\
\hline $\mathrm{T}_{5}$ & Control & Herbal immunomodulator powder & - \\
\hline $\mathrm{T}_{6}$ & Control & Herbal immunomodulator liquid & + \\
\hline $\mathrm{T}_{7}$ & Control & Herbal immunomodulator liquid & + \\
\hline
\end{tabular}


Table.2 Effect of herbal immunomodulator and levamisole on carcass characteristics in Giriraja birds

\begin{tabular}{|c|c|c|c|c|c|c|}
\hline \multirow{2}{*}{\multicolumn{2}{|c|}{ Treatment }} & \multirow{3}{*}{$\begin{array}{l}\begin{array}{l}\text { Dressing } \\
\text { percentage }\end{array} \\
75.45 \pm 0.95^{\mathrm{bc}} \\
\end{array}$} & \multirow{3}{*}{$\begin{array}{l}\begin{array}{l}\text { Abdominal } \\
\text { fat } \\
\text { percentage }\end{array} \\
1.67 \pm 0.22 \\
\end{array}$} & \multicolumn{3}{|c|}{$\begin{array}{l}\text { Organ } \\
\text { (gm/100gm body weight) }\end{array}$} \\
\hline & & & & \multirow{2}{*}{$\begin{array}{l}\text { Liver } \\
2.32 \pm 0.076 \\
\end{array}$} & \multirow{2}{*}{$\begin{array}{l}\text { Heart } \\
0.46 \pm 0.020^{\mathrm{bc}} \\
\end{array}$} & \multirow{2}{*}{\begin{tabular}{|l} 
Gizzard \\
$2.33 \pm 0.10$ \\
\end{tabular}} \\
\hline $\mathrm{T}_{1}$ & Control & & & & & \\
\hline $\mathrm{T}_{2}$ & $\begin{array}{l}\text { Control + levamisole } \\
\text { without vaccine }\end{array}$ & $77.59 \pm 0.82^{\mathrm{ab}}$ & $2.28 \pm 0.42$ & $2.35 \pm 0.092$ & $0.51 \pm 0.019^{\mathrm{ab}}$ & $2.32 \pm 0.07$ \\
\hline $\mathrm{T}_{3}$ & $\begin{array}{l}\text { Control + levamisole } \\
\text { with vaccine }\end{array}$ & $78.82 \pm 0.91^{\mathrm{a}}$ & $1.91 \pm 0.29$ & $2.31 \pm 0.12$ & $0.45 \pm 0.021^{b c}$ & $2.35 \pm 0.14$ \\
\hline $\mathrm{T}_{4}$ & $\begin{array}{l}\text { Control } \\
\text { powder } \\
\text { vaccine }\end{array}$ & $77.49 \pm 0.70^{\mathrm{ab}}$ & $2.26 \pm 0.24$ & $2.33 \pm 0.082$ & $0.52 \pm 0.029^{\mathrm{ab}}$ & $2.31 \pm 0.14$ \\
\hline $\mathrm{T}_{5}$ & $\begin{array}{l}\text { Control }+ \text { HIM } \\
\text { powder with vaccine }\end{array}$ & $77.98 \pm 0.45^{\mathrm{ab}}$ & $2.08 \pm 0.25$ & $2.33 \pm 0.09$ & $0.55 \pm 0.043^{\mathrm{a}}$ & $2.32 \pm 0.07$ \\
\hline $\mathrm{T}_{6}$ & $\begin{array}{l}\text { Control }+\begin{array}{r}\text { HIM } \\
\text { liquid } \\
\text { vaccine }\end{array} \quad \text { without } \\
\end{array}$ & $74.21 \pm 1.99^{c}$ & $2.53 \pm 0.22$ & $2.23 \pm 0.11$ & $0.49 \pm 0.030^{\mathrm{abc}}$ & $2.29 \pm 0.13$ \\
\hline $\mathrm{T}_{7}$ & $\begin{array}{l}\text { Control }+ \text { HIM } \\
\text { liquid with vaccine }\end{array}$ & $74.14 \pm 0.69^{c}$ & $2.39 \pm 0.26$ & $2.31 \pm 0.07$ & $0.42 \pm 0.016^{\mathrm{c}}$ & $2.40 \pm 0.11$ \\
\hline
\end{tabular}

Means bearing atleast one common superscript column wise does not differ significantly $(\mathrm{P} \leq 0.05)$

Table.3 Effect of herbal immunomodulator and levamisole on thigh and breast muscle weight (Percent) in Giriraja birds

\begin{tabular}{|l|l|l|l|}
\hline \multicolumn{2}{|l|}{ Treatment } & Breast muscle (\%) & Thigh muscle (\%) \\
\hline $\mathrm{T}_{1}$ & Control & $7.17 \pm 0.34$ & $3.23 \pm 0.096$ \\
\hline $\mathrm{T}_{2}$ & Control+ levamisole without vaccine & $7.72 \pm 0.39$ & $3.35 \pm 0.24$ \\
\hline $\mathrm{T}_{3}$ & Control+ levamisole with vaccine & $7.85 \pm 0.37$ & $3.38 \pm 0.18$ \\
\hline $\mathrm{T}_{4}$ & Control+ HIM powder without vaccine & $7.68 \pm 0.37$ & $3.25 \pm 0.12$ \\
\hline $\mathrm{T}_{5}$ & Control+ HIM powder with vaccine & $7.91 \pm 0.46$ & $3.26 \pm 0.11$ \\
\hline $\mathrm{T}_{6}$ & Control+ HIM liquid without vaccine & $7.91 \pm 0.34$ & $3.20 \pm 0.16$ \\
\hline $\mathrm{T}_{7}$ & Control+ HIM liquid with vaccine & $7.25 \pm 0.35$ & $3.07 \pm 0.18$ \\
\hline
\end{tabular}

Maximum relative heart weight of 0.55 per cent was observed in group supplemented with herbal immunomodulator powder with vaccine $\left(\mathrm{T}_{5}\right)$ as against the lowest relative heart weight of 0.42 per cent recorded in group supplemented with herbal immunomodulator liquid with vaccine $\left(\mathrm{T}_{7}\right)$. The highest relative heart weight value $(0.55)$ recorded in herbal immunomodulator powder with vaccine $\left(\mathrm{T}_{5}\right)$ was non- significantly comparable with other treatments $\left(\mathrm{T}_{2}, \mathrm{~T}_{4}\right.$ and
$\left.\mathrm{T}_{6}\right)$ but significantly differ in treatments $\left(\mathrm{T}_{1}\right.$, $\mathrm{T}_{3}$ and $\left.\mathrm{T}_{7}\right)$. The lowest relative heart weight (0.42) recorded in $T_{7}$ was significantly different from treatments $\left(\mathrm{T}_{2}, \mathrm{~T}_{4}\right.$ and $\left.\mathrm{T}_{5}\right)$ and non-significantly comparable with treatments $\left(\mathrm{T}_{1}, \mathrm{~T}_{3}\right.$ and $\left.\mathrm{T}_{6}\right)$. However, use of herbal preparations with herbal immunomodulator powder (with and without vaccine) and herbal immunomodulator liquid (with and without vaccine) showed non-significant difference in relative heart weight percentage. Similarly 
non-significant difference was observed among groups supplemented with levamisole powder (with and without vaccine). However, herbal immunomodulator powder with vaccine supplemented group $\left(\mathrm{T}_{5}\right)$ exhibited significantly higher relative weight compared to levamisole powder with vaccine $\left(\mathrm{T}_{2}\right)$ and with herbal immunomodulator liquid with vaccine $\left(\mathrm{T}_{7}\right)$ among the different immunomodulators. The results of present study are in agreement with the findings Raghdad and Abd Al-Jaleel (2012) revealed that the effect of turmeric in broiler diet on the giblets traits' (i.e., Dressing,Liver, Gizzard, Heart\%) at 6 weeks of age, results showed no significant differences in giblets of treated group as compared with control group.

The relative weight of gizzard ranged from as low as 2.29 per cent in group supplemented with herbal immunomodulator liquid without vaccine $\left(\mathrm{T}_{6}\right)$ to as high as 2.40 per cent in group supplemented with herbal immunomodulator liquid with vaccine $\left(T_{7}\right)$ group. There was no significant difference $(\mathrm{P}>0.05)$ in relative gizzard weights among various treatments when compared to control. The present results are also in agreement with the findings of Ali Nobakht et al., (2012) studied the effects of Satureja hortensis L. on carcass traits of broilers. The results revealed that between carcass traits only gizzard percent significantly affected by addition different levels of $S$. hortensis $L$. into broiler diets $(\mathrm{P}<0.05)$. S. hortensis L. significantly decreased the percent of gizzard. The lowest per cent of gizzard $(2.60 \%)$ was resulted by using $0.5 \%$ of $S$. hortensis L. whereas the highest percent $(3.22 \%)$ belonged to control group.

The effect of supplementation of herbal immunomodulator powder and liquid (with and without vaccine) and levamisole powder (with and without vaccine) on breast muscle yield (Table 3). Among the various treatment groups maximum relative breast muscle weight (7.91 per cent) was recorded in herbal immunomodulator powder with vaccine $\left(\mathrm{T}_{5}\right)$ and herbal immunomodulator liquid without vaccine supplemented group $\left(\mathrm{T}_{6}\right)$ as against the lowest relative breast muscle weight of 7.17 per cent recorded in control $\left(\mathrm{T}_{1}\right)$. There was no significant difference in relative weight of breast muscle weights among various treatments when compared to control and also among the different treatment groups. The results of present study are also in agreement with the finding of ${ }^{8}$ numerically addition of Satureja hortensis L. Relative improvement of abdominal breast per cents were observed in group fed $1.5 \%$ Satureja hortensis L.

The effect of supplementation of herbal immunomodulator powder and liquid (with and without vaccine) and levamisole powder (with and without vaccine) on thigh muscle (Table 3). Among the various treatment groups maximum relative thigh muscle weight (3.38 per cent) was recorded in group supplemented with levamisole with vaccine $\left(\mathrm{T}_{3}\right)$ as against the lowest relative thigh muscle weight of 3.07 per cent recorded in group supplemented with herbal immunomodulator liquid with vaccine $\left(\mathrm{T}_{7}\right)$. There was no significant difference in relative weight of thigh muscle weights among various treatment groups when compared to control and also among the different treatment groups. The present results are in agreement with the findings of Alireza Safamehr et al., (2012) found that the carcass characteristics and thigh yield of female broilers, was not significantly $\quad(\mathrm{P}>0.05)$ affected by supplementation of the diet with nettle.

\section{References}

Ali Nobakht, Mehrab Nobakht, and Ali Reza Safamehr. 2012. The effect of different levels of savory medicinal plant 
(Satureja hortensisL.) on growth performance, carcasstraits, immune cells and blood biochemical parameters of broilers. Afr. J. Agri. Res., 7(10):1456-1461.

Alireza safamehr, Mostafa mirahmadi, and Ali nobakht, 2012. Effect of nettle (Urtica dioica) medicinal plant on growth performance, immune responses, and serum biochemical parameters of broiler chickens. Int. Res. J. Applied and Basic Sci., 3(4):721-728.

Arivuchelvan, A., Murugesan, S., Mekala, P., and Yogeswari, R. 2012. Immunomodulatory effect of Ocimum sanctum in broilers treated with high doses of gentamicin. Indian J. Drugs and Dis., 1(5): 109-112.

Basmacioblu, H., Tokudoblu, O. and Ergul, M. 2004. The effect of oregano and rosemary essential oils or alphatocopheryl acetate on performance and lipid oxidation of meat enriched with n3 PUFA's in broilers. S. Afr. J. Anim.
Sci., 34:197-210.

Ensminger, M. E., Oldfield, J. E. and Heinemann, W. W., 1990. Feeds and Nutrition, p. 1544.

Ganguly, S., and Prasad, A. 2010. Role of plant extracts and cow urine distillate as immunomodulator in comparison to Levamisole - A Review, J. Immunol. Immunopathology, 12(2): 91-94.

Raghdad, A., and Al-Jaleel. 2012. Use of turmeric (Curcuma longa) on the performance and some physiological traits on the broiler diets. The Iraqi J. Vet. Med., 36(1): 51- 57.

Salarya, J., Kalantarb, M., Sahebi Alac, M., Ranjbard, K., Hemati and Matine, $\mathrm{H}$. R., 2014. Drinking water supplementation of licorice and aloe vera extracts in broiler chickens. Scientific J. Ani. Sci., 3(2): 41-48.

William, P., and Losa, R. 2001. The Use of Essential Oils and Their Compounds in Poultry Nutrition. World's Poult, 17(4): 14-15.

\section{How to cite this article:}

Dharmaraj, G.Y., Jayanaik, H.C. Indresh and Munegowda, T. 2017. Effect of Herbal Immunomodulator on Dressing Percentage and Carcass Characteristics of Giriraja Birds. Int.J.Curr.Microbiol.App.Sci. 6(9): 1436-1441. doi: https://doi.org/10.20546/ijcmas.2017.609.174 